NBSIR 73-301

Development of Insulation Transfer-Standards Using a Flat Plate Calorimeter

P. R. Ludtke

Cryogenics Division

Institute for Basic Standards

National Bureau of Standards

Boulder, Colorado 80302

March 1973

Prepared for

NASA-Marshall Space Flight Center

Astronautics Laboratory

Materials Division

Huntsville, Alabama 



\section{DEVELOPMENT OF INSULATION TRANSFER-STANDARDS \\ USING A FLAT PLATE CALORIMETER}

P. R. Ludtke

Cryogenics Division

Institute for Basic Standards

National Bureau of Standards

Boulder, Colorado 80302

March 1973

Prepared for

NASA-Marshall Space Flight Center

Astronautics Laboratory

Materials Division

Huntsville, Alabama

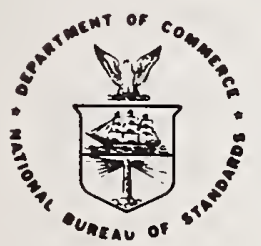

U.S. DEPARTMENT OF COMMERCE, Frederick B. Dent, Secretary NATIONAL BUREAU OF STANDARDS, Richard W. Roberts, Director 



\section{CONTENTS}

1. 0 Introduction . . . . . . . . . . . . . . . . . 1

2. 0 Evaluation of the Various Insulation Materials . . . . . 4

3. 0 Selection of Calorimeter . . . . . . . . . . 6

4. 0 Selection of Candidate Insulation Materials for Preliminary

Evaluation . . . . . . . . . . . . . . 7

4.1 Basis for Selection of Candidate Materials . . . . 7

4. 1.1 Closed Cell Foams . . . . . . . . . 8

4. 1.2 Open Cell Foams . . . . . . . . . . 8

4. 1. 3 Powders and Opacified Powders . . . . . . 8

4.1.4 Glass Microspheres . . . . . . . . 9

4.1.5 Fiber Glass . . . . . . . . . . . . 9

4. 1.6 Multi-Layer Materials . . . . . . . . 9

4. 2 Selection of Candidate Materials for Preliminary

Testing . . . . . . . . . . . . . . . . 10

4.2.1 Closed Cell Foams . . . . . . . . . 10

4.2.2 Open Cell Foams . . . . . . . . . 13

4.2.3 Powders, Opacified Powders, and Glass

Microspheres . . . . . . . . . . 13

4.2. 4 Fiber Glass . . . . . . . . . . . . 15

4.2.5 Multi-Layer Materials . . . . . . . 15

5. 0 Preparation of Samples for the MSFC Flat Plate Calorimeter 16

5. 1 Foams, Closed and Open . . . . . . . . 16

5.2 Fiber Glass Samples . . . . . . . . . . 17

5. 3 Multi-Layer Transfer-Standards . . . . . . . 19

6. 0 Evaluation of the Condition of the MSFC Calorimeter, the Accompanying Instrumentation, and the Data Reduction Procedures . . . . . . . . . . . . . . 21 
7. 0 Draft of an Interim Operating Procedure . . . . . . . 27

7. 1 Typical Test Procedure . . . . . . . . . 28

7. 1.1 Closed Cell Foam Transfer-Standards . . . . 28

7. 1.2 Open Cell Foam Samples . . . . . . . 31

7.1.3 Fiber Glass and Multi-Layer Sandwiches . . 31

8. 0 Preliminary Screening Tests with the MSFC Calorimeter on Selected Candidate Transfer-Standards . . . . . . . 32

8.1 Discussion of Test Results . . . . . . . . . . 32

8.1.1 Closed Cell Foams . . . . . . . . . 32

8.1.2 Open Cell Foams . . . . . . . . . 36

8.1.3 Fiber Glass Transfer-Standard . . . . . 37

8.1.4 Multi-Layer Transfer-Standard . . . . . 37

9.0 Future Work . . . . . . . . . . . . . 38 


\section{ILIST OF FIGURES}

Figure 1. Thermal conductivity of pertinent gases . • • • • 12

Figure 2. Open cell foam, NBS-MSFC-100 . . . . . . . . . 14

Figure 3. Fiber glass sandwich . • . • . . • . • . . . 18

Figure 4. Multi-layer container . . • . • . . . . . . . . 22

Figure 5. Complete multi-layer sandwich . . . . • . . . . 23

Figure 6. Double Guarded Flat Plate Calorimeter . • • • . 24

\section{LIST OF TABLES}

Table 1. Sandwich Type Multi-Layer Samples . . . . . . . 20

Table 2. Thermal Conductivity Test Results . • . . • . • . 33

Continued . . . . . . . . . . . . . . 34 

DEVELOPMENT OF INSULATION TRANSFER-STANDARDS

USING A FLAT PLATE CALORIMETER

P. R. Ludtke

This program was initiated to develop insulation transfer-standards to be used for evaluating calorimeters at different locations throughout the country. Various types of insulation materials were evaluated for use as transfer-standards. Samples were prepared for preliminary evaluation from selected candidate insulation materials. A $30.5 \mathrm{~cm}$ diameter double guarded flat plate calorimeter at MSFC was provided for testing. The calorimeter was checked and the boiloff-gas instrumentation updated. Thermal conductivity screening tests were conducted using liquid nitrogen on open and closed cell foam and fiber glass samples. The mean thermal conductivity values of the samples tested during the screening tests are presented. Compliance with the proposed ASTM Standard Method of Test for Heat Flux Through Evacuated Insulations was stressed.

\section{0 Introduction}

Insulation systems for cryogenic fluids require a wide range of insulation materials of varying quality; at present, no adequate means exist for evaluating new or improved insulation concepts or for comparing different insulation materials under the same conditions in different laboratories at different times. The objective of this study is to develop materials, equipment, and procedures that will readily permit evaluation and comparison of insulation materials in any competent laboratory. In essence, cryogenic insulation transferstandards will be developed along with the necessary equipment and procedures. 
The general approach to the program is as follows. A literature search for information on cryogenic insulation materials and also on thermal insulation calorimeters was conducted. The various insulation material properties were studied and candidate materials were selected for evaluation. The various types of calorimeters for measuring thermal conductivity were studied and the measuring techniques and parameters were evaluated. The calorimeter used for the experimental tests in this program was a double guarded flat plate model located at the NASA-Marshall Space Flight Center. The condition of the calorimeter, the accompanying instrumentation, and the test procedure were evaluated. Recommendations were made for improving the calorimeter precision and an interim test procedure was drafted for use in the preliminary screening tests. Samples of the selected types of insulation materials were prepared for screening tests and for subsequent repeatability tests in the calorimeter. From the screening tests, the most promising materials were to be selected for further testing. At present, the initial screening tests have been conducted using liquid nitrogen on all but the multi-layer samples; the multi-layer screening tests will be conducted using liquid hydrogen.

Future work to be completed in the program is planned as follows. Before starting the liquid hydrogen testing of the multi-layer samples, the present interim test procedure will be modified to follow as closely as possible, the proposed ASTM Standard Method of Test for Heat Flux Through Evacuated Insulations Using a Guarded Flat Plate Boiloff Calorimeter. This document is now in its fifth draft revision. Also, the Calorimeter at MSFC will be modified and updated to meet the requirements of the proposed Standard Method of Test. Screening tests will then be conducted on the multi-layer samples using 
liquid hydrogen. From the screening tests, the most promising sample materials will be selected for further repeatability testing. After the repeatability tests, final sample materials will be selected for the three different thermal conductivity ranges of 0.1 to 1,1 to 50 , and 50 to $300 \mathrm{\mu W} / \mathrm{cm}-\mathrm{K}$. Transfer-standards will then be prepared for each of the above thermal conductivity ranges. The transfer-standard samples will be tested, assigned a thermal conductivity value, and will be made available for comparative testing in other flat plate calorimeters throughout the country. The thermal conductivity of the transferstandards will be checked periodically to determine the measurement uncertainty of the thermal conductivity value assigned to that material and to determine long term aging effects.

After selecting the multi-layer materials that are most reproducible, they will be tested on an operational dewar. A large dewar of practical size will be insulated with the chosen multi-layer materials, using normal care and application techniques. The effective thermal conductivity of the same multi-layer materials on the large dewar will be determined by appropriate testing, for comparison with the calorimeter results.

From the information gained during the screening and repeatability tests, design criteria for what is considered an optimum standard calorimeter will be formulated. Design criteria will include ease of operation, pressure loading capability, flexible operating capability, minimum operating cost, and compliance with the ASTM proposed standard. During the program, the temperature range of interest will be confined to 20 to $300 \mathrm{~K}$. During the screening and repeatability tests there will be no variation of compressive force on the samples; the effect of compressive force on the thermal conductivity of 
the samples will not be investigated. Considerable emphasis will be placed on the multi-layer insulation (MLI) region of thermal conductivity and adherence to the proposed ASTM standard method of test for MLI.

\section{0 Evaluation of the Various Insulation Materials}

In order to gather all of the pertinent information on thermal insulations, a literature search was conducted. Two bibliographies were compiled; one entitled, "The Properties of Thermal Insulations" and a second entitled, "Thermal Insulation Systems." Pertinent documents aided in the selection of insulation materials having constancy of properties and exhibiting characteristics desirable for transfer-standards.

The cryogenic thermal insulation materials were grouped into the following categories for evaluation:

1) Closed Cell Foams: These foams are made of polyurethane or polystyrene and usually have a chlorofluorocarbon or carbon dioxide gas within the closed cells. The densities range from 32 to $641 \mathrm{~kg} / \mathrm{m}^{3}$ ( 2 to $40 \mathrm{lb} / \mathrm{ft}^{3}$ ) and the foam is usually rigid. These foams will be tested in a non-evacuated environment. The foams are available in rigid boardstock, or they may be poured, frothed, or sprayed.

2) Open Cell Foams: These foam materials have a high percentage $(60-95 \%)$ of open cells, the foam may be rigid, semi-rigid, or flexible. The density is usually in the range of $32 \mathrm{~kg} / \mathrm{m}^{3}\left(2 \mathrm{lb} / \mathrm{ft}^{3}\right)$. The open cell foams will be tested under evacuated conditions. Some of the open cell foam materials are polyurethane and polyphenyl oxide (PPO). An opacifier material such as aluminum powder possibly could be blended into the foam mixture before rise occurs to make an opacified open cell foam. 
3) Powders: Powders such as perlite, silica aerogel, and pyrogenic silicates comprise another group of insulating materials. These materials are difficult to handle, contain, and evacuate. They may be tested with opacifiers such as copper or aluminum flakes, or aluminum powder. The powders are usually silicon oxides and tested under evacuated conditions.

4) Fiber Glass: Fiber glass of various texture is available (mat., blanket, etc.) and can be obtained with very few impurities. The fiber glass may also be combined with reflective shields, and will be tested under evacuated conditions.

5) Glass Microspheres: Microspheres are very small ( 15 to 150 microns diameter) hollow glass beads which may be completely or hemispherically coated with aluminum, or not coated at all. The thermal conductivity of the microspheres is comparable to other opacified powder systems. The microspheres are difficult to handle, contain, and evacuate. The microspheres are normally used under evacuated conditions.

6) Multi-Layer Insulations: Various types of multi-layer insulation materials are available. The shields usually consist of polyethylene terephthalate (PETP) or polypyromelitimide (PPMI) film which is thinly coated with aluminum, silver, or gold on one or both sides. The base material is sometimes given a crinkled or 
waffled texture. The PPMI film is more expensive and has a higher temperature limit $(400 \mathrm{C})$ than PETP film (137 C), therefore, PPMI is normally used only when the higher temperature capability is a necessity. When a reflective metal coating is used only on one side, the base material is sometimes krinkled or dimpled and used with no spacer material. Aluminum foil is also used for shields.

Various types of thin insulating spacer materials may be used between the shields, e. g. , glass paper, glass matting, silk net, nylon net, and polyurethane foam. These spacers have varied outgassing characteristics and moisture absorption properties.

There is one type of composite multi-layer insulation which is different from the others. It is made by cementing small tufts of PEPT fibers to a shield material such as aluminized PEPT or PPMI film. The tufts serve the same purpose as the other types of spacer materials, and promote evacuation of the multi-layer system. Multi-layer insulations are always used in an evacuated environment.

\section{0 Selection of Calorimeter}

Literature pertinent to the measurement of the rmal conductivity using calorimeters was compiled and reviewed, including the ASTM Special Technical Publication No. 411 entitled "Thermal Conductivity Measurements of Insulating Materials at Cryogenic Temperatures。" It became apparent, after review, that the type of calorimeter best suited 
for a standard testing device for cryogenic insulation materials is the double guarded flat plate calorimeter. This calorimeter is undoubtedly the most complicated thermal conductivity apparatus, but it is also the most versatile and probably the most accurate. A double guarded flat plate calorimeter allows one to measure thermal conductivity versus uniform compressive force on the sample materials and to measure the precise thickness of the sample up to 2 inches before and during the test. The temperature of the guard shield near the edge of the sample can be measured and controlled and thus the edge effects of multi-layer insulation can be investigated and controlled while the thermal conductivity of the sample can be measured in various gas environments ranging in pressure from $10^{-6}$ to 760 torr. The cold and warm plates of the calorimeter have a tremendous temperature range and the calorimeter will measure thermal conductivities over various temperature intervals of the cryogenic range. Visual capability is also available on some of these calorimeters. This calorimeter is without a doubt the best contender for a standard thermal conductivity tester and affords the best control of the parameters important in developing insulation transfer standards.

4. 0 Selection of Candidate Insulation Materials for Preliminary Evaluation

4. 1 Basis for Selection of Candidate Materials

Most of the insulation materials presently available were considered. Some were selected for preliminary evaluation and testing by considering the characteristics and properties deemed most important for a cryogenic transfer-standard material. These characteristics and properties are listed below for the various groups of insulation materials. 


\section{1.1 Closed Cell Foams}

1) Change of thermal conductivity with time (gas equilibration rate)

2) The type and thermal conductivity of the gas within the cells

3) Water absorption

4) Foam cell size

5) Density uniformity

6) Dimensional stability

7) Surface dusting and discoloration due to aging

8) Tendency to crack at cryogenic temperatures.

\section{1.2 Open Cell Foams}

1) Percentage of open cells

2) Rigid or flexible

3) Foam cell size

4) Water absorption

5) Density uniformity

6) Surface dusting and discoloration due to aging

7) Tendency to crack at cryogenic temperatures.

\section{1. 3 Powders and Opacified Powders}

1) Ease of handling and testing in a flat plate calorimeter

2) Containment of the powder in a suitable enclosure during a calorimeter test

3) Moisture absorption

4) Maintaining uniform distribution of the opacifier within the powder

5) Powder loss due to handling a confined sample in a porous envelope over a period of time.

6) Compaction of the powder due to handling. 
1) Ease of handling and testing in a flat plate calorimeter

2) Containment of the microspheres in a suitable enclosure during a calorimeter test

3) Loss of microspheres due to handling a contained sample in a porous envelope over a period of time

4) Higher cost of the microspheres.

\section{1.5 Fiber Glass}

1) Packaging of the fiber glass sample in a suitable container that would allow the sample to be handled and transferred

2) Possibly combining the fiber glass with reflecting shields to make a composite sample

3) Uniform density of the fiber glass

4) Outgassing of the binder and lubricant normally used in manufacturing fiber glass.

\section{1.6 Multi-Layer Materials}

[Multi-Layer Shield Materials]

1) Emissivity of the metal coating

2) Oxidation susceptibility or long term emissivity of the material

3) Thickness of the vapor deposited coating (usually determined by measuring the electrical resistivity of the coating)

4) Upper temperature limit of the base material

5) Long term outgassing and chemical decomposition characteristics

6) Lateral thermal conductivity

7) Type of metal coating 
8) Cost of the shield materials

9) Total thickness of shield

10) Texture of the material (crinkled, dimpled, waffled, tufted, or flat)

11) Metallized on one or both sides, or plain foil.

[Multi-Layer Spacer Materials]

1) Thickness and density of the spacer material

2) Water absorption characteristics

3) Long term chemical decomposition

4) Upper temperature limit

5) Cost

6) Type of material

7) Tensile strength

8) Lateral thermal conductivity

9) Type of spacer material (paper, blanket, or tufts)

10) Outgassing characteristics.

4. 2 Selection of Candidate Materials for Preliminary Testing Candidate materials were chosen and divided into five basic groups. The materials chosen were judged best suited for transferstandard materials using the criteria outlined in the previous section. The materials chosen for each group are listed below.

\subsection{Closed Cell Foams}

Three closed cell foams were chosen: each is described below. Polyurethane foam NBS-MSFC-4 is a rigid foam containing carbon dioxide gas. Foams containing $\mathrm{CO}_{2}$ gas usually have a higher thermal conductivity than foams containing chlorofluorocarbon gas. The $\mathrm{CO}_{2}$ gas also has the characteristic of diffusing from the foam at a 
faster rate than the chlorofluorocarbon gases. $\mathrm{A} \mathrm{CO}_{2}$ blown foam was chosen because it should have a shorter equilibration time and hence can attain a uniform thermal conductivity sooner. The thermal conductivity of various pertinent gases at one atmosphere is shown in figure 1. This foam also has a high degree of dimensional stability, an exceptionally uniform density, an isotropic cell structure, and a rated mean thermal conductivity of $360 \mathrm{uW} / \mathrm{cm}-\mathrm{K}$. The foam is white and has very little tendency to dust at the surface.

The second foam chosen is NBS-MSFC-6. This is a rigid polyurethane foam of $64 \mathrm{~kg} / \mathrm{m}^{3}\left(4 \mathrm{lb} / \mathrm{ft}^{3}\right)$. The closed cells contain mostly chlorofluorocarbon gas which has a relatively low thermal conductivity, as indicated in figure 1 . The foam has a rated thermal conductivity of 159 initially and $202 \mathrm{u} \mathrm{W} / \mathrm{cm}-\mathrm{K}$ after aging and equilibrating with air. The water absorption characteristics of the foam are the same as the $\mathrm{CO}_{2}$ blown NBS-MSFC-4 foam, but the dimensional stability is not nearly as good. The foam also tends to have a dusty surface, or dusting tendency. The chlorofluorocarbon gas diffuses from the foam considerably slower than the $\mathrm{CO}_{2}$.

The third closed cell foam chosen for evaluation is NBS-MSFC-3.

This is rigid polystyrene foam, with high load bearing properties. The closed cells are filled mostly with chlorofluorocarbon gas. The surface is hard and has no tendency to dust. The foam has an initial mean thermal conductivity of $202 \mathrm{\mu W} / \mathrm{cm}-\mathrm{K}$ which increases slightly with age as the air replaces a portion of the chlorofluorocarbon gas within the cells. The foam has an approximate density of $54 \mathrm{~kg} / \mathrm{m}^{3}$ $\left(3.4 \mathrm{lb} / \mathrm{ft}^{3}\right)$ and is of very uniform density. 


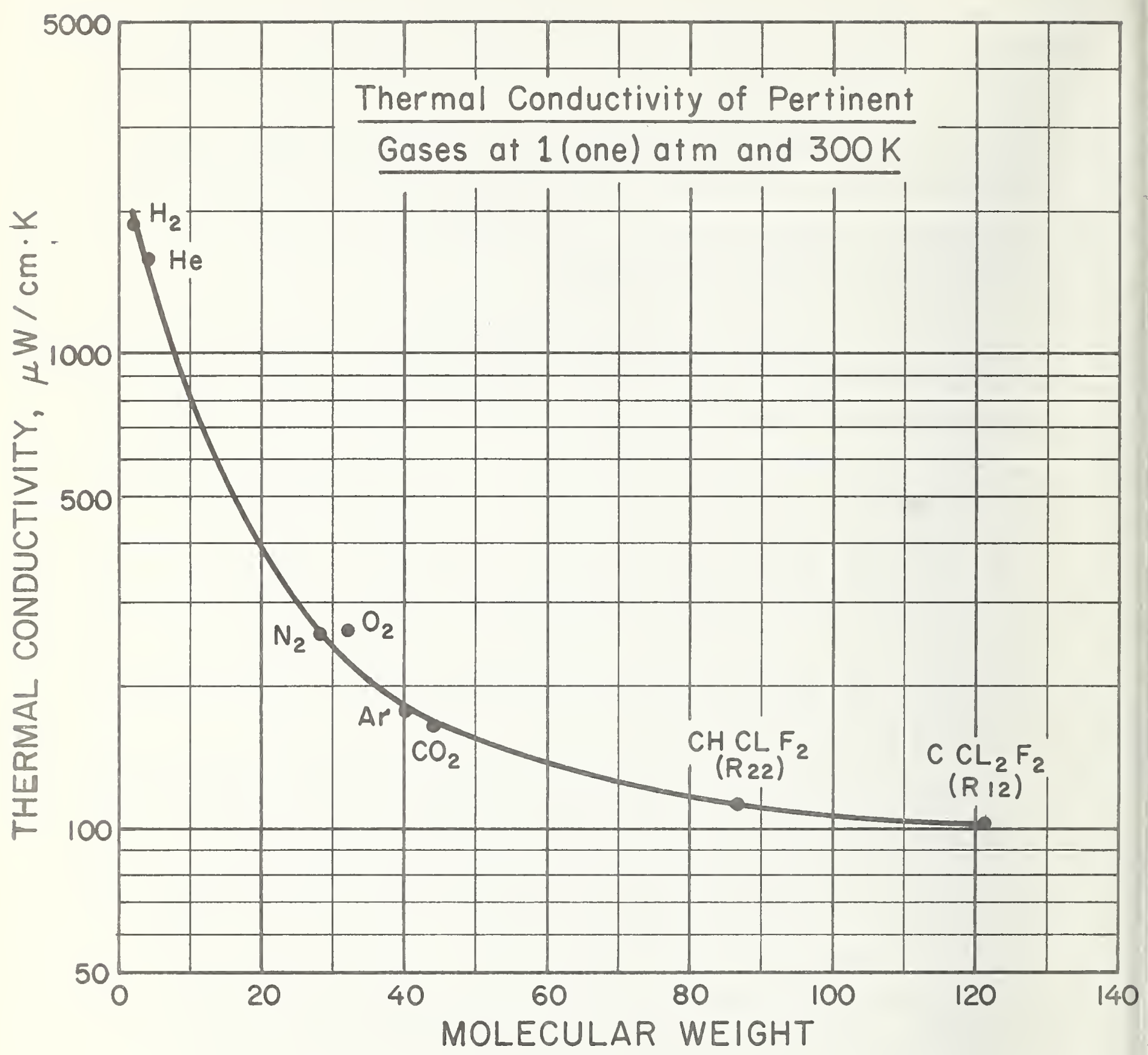

Figure 1. Thermal conductivity of pertinent gases. 


\subsection{Open Cell Foams}

Two open cell foams were chosen as candidate materials to be tested under evacuated conditions.

The first is an experimental rigid polyurethane foam designated as NBS-MSFC-100. The foam has a density of $32 \mathrm{~kg} / \mathrm{m}^{3}\left(2 \mathrm{lb} / \mathrm{ft}^{3}\right)$ and has a texture similar to other closed cell polyurethane foams. The open cell content of the foam is $\sim 60$ to $70 \%$. A photo of a $3.81 \mathrm{~cm}$ ( $11 / 2$ inch) thick $\times 3.05 \mathrm{~cm}$ (12 inch) diameter sample of this foam is shown in figure 2 .

The other open cell foam is polyphenyl oxide, usually called PPO. Polyphenyl oxide foam has a fibrous cell structure which is anisotropic and considerably different from the conventional round or elongated cells in most other foams. The fibers are very tough and special techniques have to be used in cutting the foam to the desired size. The cells are elongated and parallel to the foam fibers. The foam is slightly flexible when a force is applied perpendicular to the fibers. The foam has an average density of 40 to 48 $\mathrm{kg} / \mathrm{m}^{3}\left(2.5\right.$ to $\left.3 \mathrm{lb} / \mathrm{ft}^{3}\right)$.

4.2.3 Powders, Opacified Powders, and Glass Microspheres

None of the powder insulations were chosen as candidate materials because of 1 ) the problem of packaging and containing a powder sample over an extended period of time, 2) the high water absorption characteristics of the powders, and 3) the thermal conductivity range of the evacuated powders is provided at the high end by the evacuated foams and at the low end by the fiber glass. The thermal 


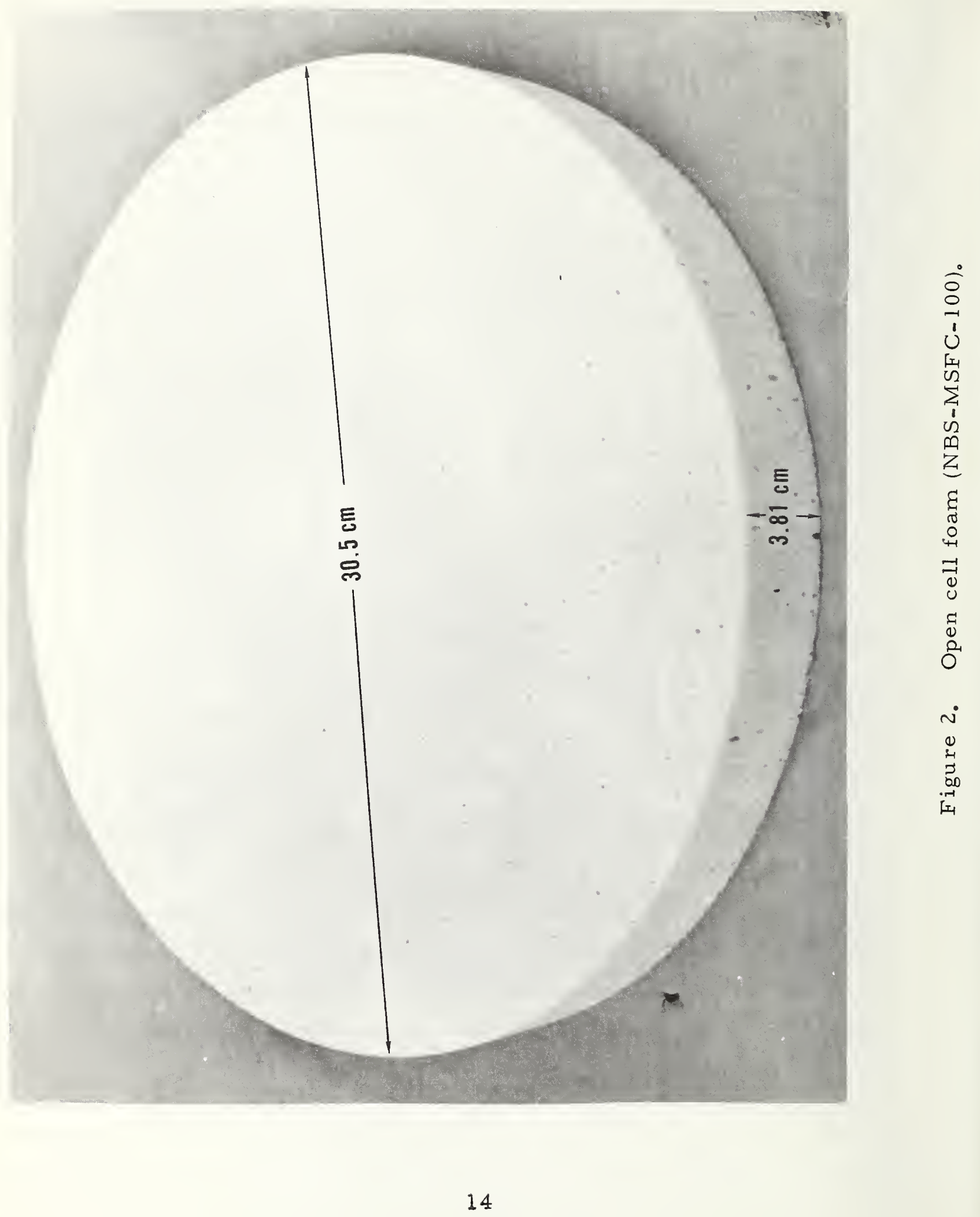


conductivity span of the opacified powders and microspheres is also provided by the fiber glass or fiber glass-multi-layer laminates. Hence, opacified powders and microspheres were eliminated as candidates for transfer-standard mate rials.

\subsection{Fiber Glass}

A special unbonded, unlubricated glass fiber material was chosen for evaluation. The fiber glass is a flexible, resilient blanket composed of glass fibers supplied without a binder or lubricant, having a density of $16 \mathrm{~kg} / \mathrm{m}^{3}\left(1 \mathrm{lb} / \mathrm{ft}^{3}\right)$. This material was chose primarily because it is free of impurities such as chlorides and oils which would tend to outgas under vacuum. Fiber glass is easily evacuated, absorbs very little water, and can be easily contained and packaged for use as a transfer-standard. Fiber glass may also be easily combined with reflecting shields to fabricate a composite sample more resistant to radiation heat transfer with a correspondingly lower thermal conductivity.

\subsubsection{Multi-Layer Materials}

A wide variety of multi-layer shield and spacer materials are available. The following were chosen as candidate materials for evaluation.

Reflecting Shield Materials:

1) PPMI film, with PETP fiber tufts, silvered on both sides

2) PETP film, waffled, silvered on both sides

3) PETP film, plain, aluminized on both sides. Each of the above shield materials is $0.0064 \mathrm{~mm}(0.00025 \mathrm{in})$ thick. 
Spacer Materials:

1) Glass mat, $0.1 \mathrm{~mm}(0.004$ in) thick

2) Borosilicate glass paper, nominal thickness of $0.023 \mathrm{~mm}(0.0009 \mathrm{in})$, density $=0.180 \mathrm{gms} / \mathrm{cm}^{3}$

3) $100 \%$ silk netting, NBS-MSFC-55.

A shield material with gold metallizing was not included because of its higher cost, especially when purchased in small quantities. Polyurethane foam spacer material was eliminated because of its high outgassing characteristics.

The above multi-layer materials will be used in various combinations to prepare composite sandwich type samples for testing. The preparation and details of construction of these sandwiches will be discussed in the next section.

5. 0 Preparation of Samples for the MSFC Flat Plate Calorimeter

The following samples were machined or prepared for testing in the MSFC calorimeter.

\section{I Foams, Closed and Open}

All of the foam samples were cut or machined into $30.5 \mathrm{~cm}$ (12 in) diameter by $3.8 \mathrm{~cm}$ ( $1.5 \mathrm{in})$ thick discs. The flat plate calorimeter will accommodate samples with a maximum thickness of $5.08 \mathrm{~cm}$ ( $2 \mathrm{in}$ ). It was decided that the foam samples should be fairly thick $3.81 \mathrm{~cm}(1.5 \mathrm{in})$, since foam is normally used in practical applications with a thickness of 5 to $15 \mathrm{~cm}$ ( 2 to 6 in). Three discs each of the following foam materials were prepared.

1) NBSrMSFC-3, closed cell polystyrene foam

2) NBS-MSFC-6, closed cell polyurethane foam 
3) NBS-MSFC-4, closed cell polyurethane foam

4) Polyphenyl Oxide, open cell foam

5) NBS-MSFC-100, experimental open cell polyurethane foam.

An attempt was made to make some foam samples of the

NBS-MSFC-100 foam containing $1 \%$ by volume of powdered aluminum as an opacifier. However, this effort failed because the foam would not rise properly。

Thus, a total of 15 foam samples were cut or machined and stored in sealed containers for subsequent testing and evaluation in the calorimeter at MSFC.

\section{2 Fiber Glass Samples}

Two different sandwiches using fiber glass were prepared. One sandwich is $3.8 \mathrm{~cm}$ thick $\times 30.5 \mathrm{~cm}$ diameter and is constructed in the following manner. A $1.3 \mathrm{~cm}$ wide $\times 3.8 \mathrm{~cm}$ ring of NBS-MSFC-100 open cell foam forms the outer ring of the sandwich. A $30.5 \mathrm{~cm}$ diameter disc of $0.05 \mathrm{~mm}(0.002$ in) thick PETP is then cemented to one side of the foam ring. The precut disc of untreated, unbonded, unlubricated fiber glass of $3.8 \mathrm{~cm}(1.5 \mathrm{in})$ thickness is then placed inside the foam ring. A similar $0.05 \mathrm{~mm}$ thick PETP disc is then cemented onto the top of the foam ring. The $30.5 \mathrm{~cm}$ diameter PETP covers are perforated with twelve $6.4 \mathrm{~mm}$ diameter holes to facilitate evacuation of the fiber glass. A photo of this sandwich is shown in figure 3.

A second sandwich using fiber glass and reflecting shields of $0.0064 \mathrm{~mm}(0.00025 \mathrm{in})$ thick double aluminized PETP film was also constructed in a similar manner. For this sandwich, the foam ring was $1.27 \mathrm{~cm}(0.05 \mathrm{in})$ wide $\times 1.9 \mathrm{~cm}(0.75 \mathrm{in})$ thick. Similar $30.5 \mathrm{~cm}$ diameter, $0.05 \mathrm{~mm}$ thick PETP covers were used to make a complete 


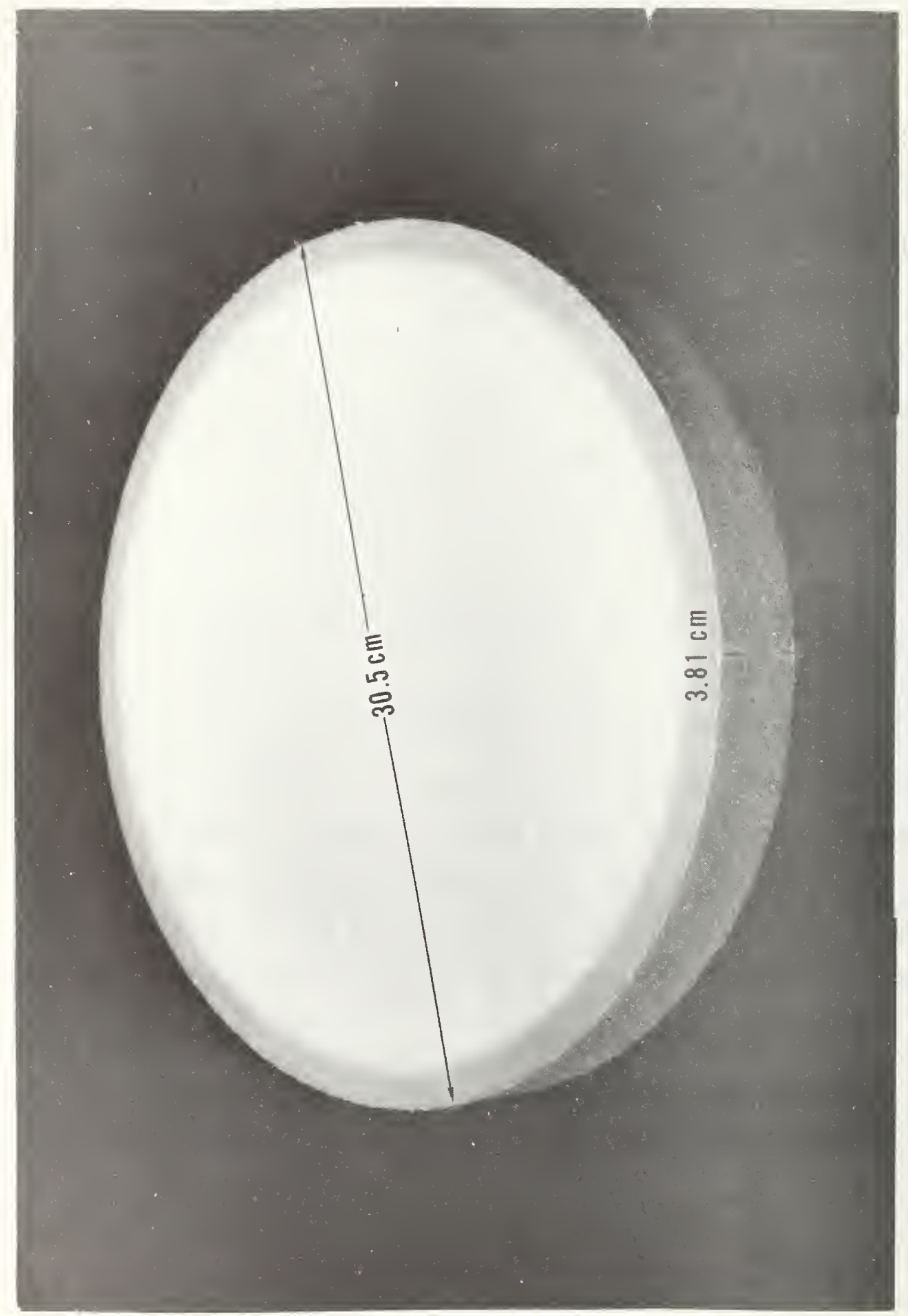

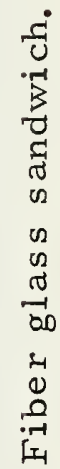

$m$
0
2
2
0
01
$i=1$ 
sandwich of $1.9 \mathrm{~cm}$ thick $\mathrm{x} 30.5 \mathrm{~cm}$ diameter. Inside the sandwich, there are 19 layers of $0.25 \mathrm{~mm}$ (0.010 in) thick fiber glass spacers with 18 alternate layers of $0.0064 \mathrm{~mm}(0.00025 \mathrm{in})$ thick aluminized PETP film A layer of fiber glass is next to each perforated PETP cover to facilitate evacuation of the sample interior.

Only one of each of these fiber glass samples was prepared for preliminary evaluation. Complete specifications such as layer density, weight density, and total weight are given in table 1.

\section{3 Multi-Layer Transfer-Standards}

Five multi-layer samples were prepared using the sandwich construction described in the previous section. The sandwich configuration was developed for the multi-layer insulations because of their extreme susceptibility to damage with normal handling. Some containment or envelope is necessary to keep the sample clean, to allow handling without physical damage, to allow handling without touching the low emissivity shield surfaces, and to allow good evacuation within the layers of the insulation. Transfer-standards will have to be shipped to various geographical locations for calorimeter testing; it is felt that the sandwich type of construction is well suited for protecting the insulation samples during shipping and handling.

The sandwich construction also provides a buffer insulation around the circumferential edge of the multi-layer insulation. The foam will minimize edge effects on the multi-layer insulation. All of the multi-layer samples are of the sandwich construction, and all are 1. 9 $\mathrm{cm}$ thick $\times 30.5 \mathrm{~cm}$ diameter. The shields and spacer materials are cut with templates to a diameter of $27.3 \mathrm{~cm}$. The free height (the height of the multi-layer discs with no external compressive force) of each of the 


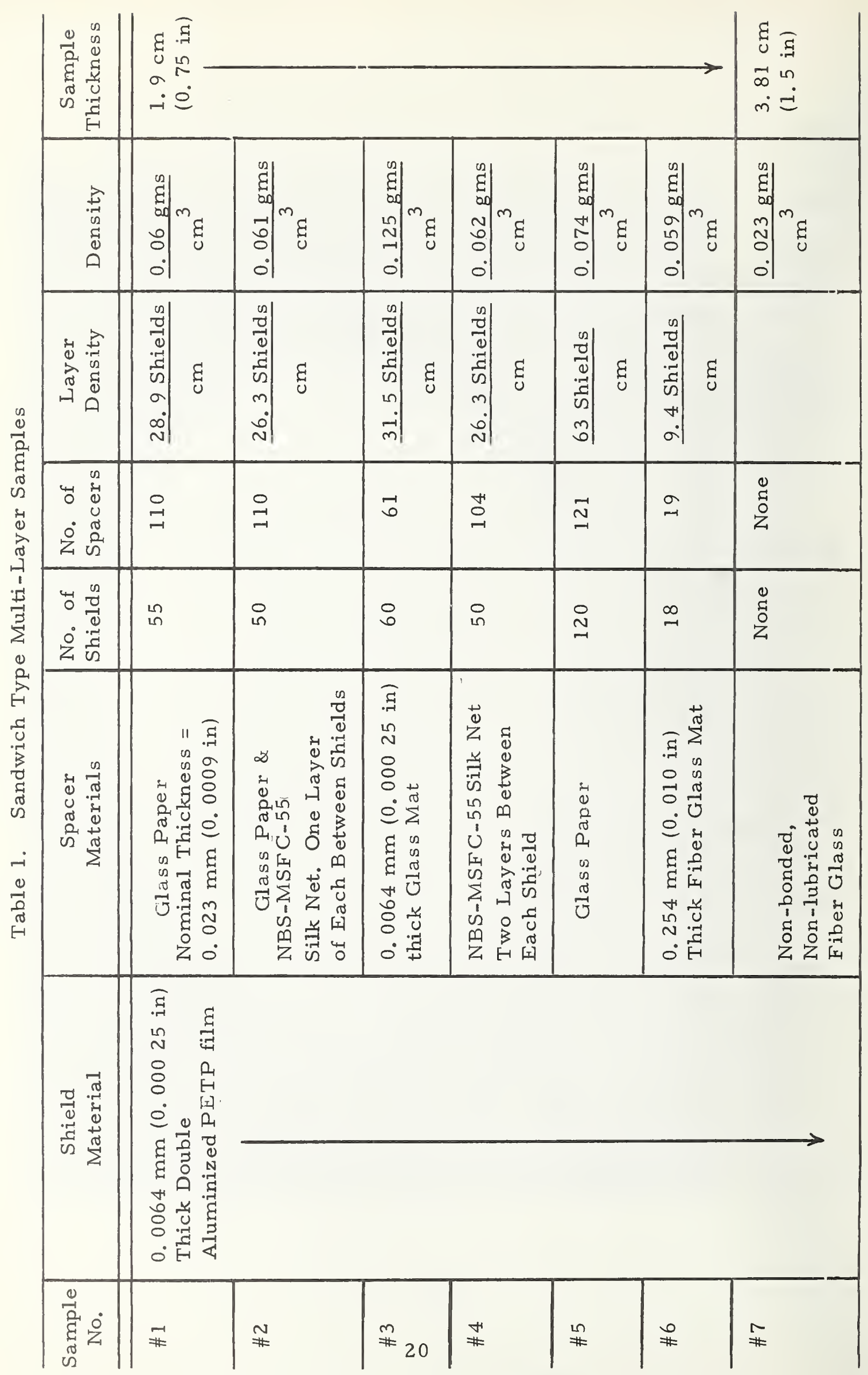


multi-layer samples is $1.9 \mathrm{~cm}$. A photo of an empty multi-layer container is shown in figure 4 , and a photo of the complete sandwich is shown in figure 5. Table 1 contains all of the information pertinent to the multi-layer samples. Two other samples using silvered PPMI film and silvered, waffled PETP have not yet been constructed because of delays in material delivery.

6. 0 Evaluation of the Condition of the MSFC Calorimeter, the Accompanying Instrumentation, and the Data Reduction Procedures

NBS personnel visited the Marshall Space Flight Center to assist in determining the condition of the calorimeter at that facility. A cross section diagram of the calorimeter is shown in figure 6. The calorimeter and accompanying instrumentation were carefully examined. The normal test procedure and data reduction procedures were also reviewed.

As a result of this evaluation, recommendations were submitted to MSFC. Methods of improving the accuracy of the thermal conductivity measurements and of updating the calorimeter instrumentation were suggested as follows:

1) That the original measuring and guard vessel pressure controller, which decreased atmospheric pressure variations by a factor of 36 , be reconnected, or that a cartesian diver type manostat with a controlled temperature bath be used to control the pressure in the measuring vessel.

2) That a new wet test meter of the proper size be purchased and used for boil-off rates of about $0.08 \mathrm{~cm}^{3} / \mathrm{sec}(0.01$ $\mathrm{ft}^{3} / \mathrm{hr}$ ). 


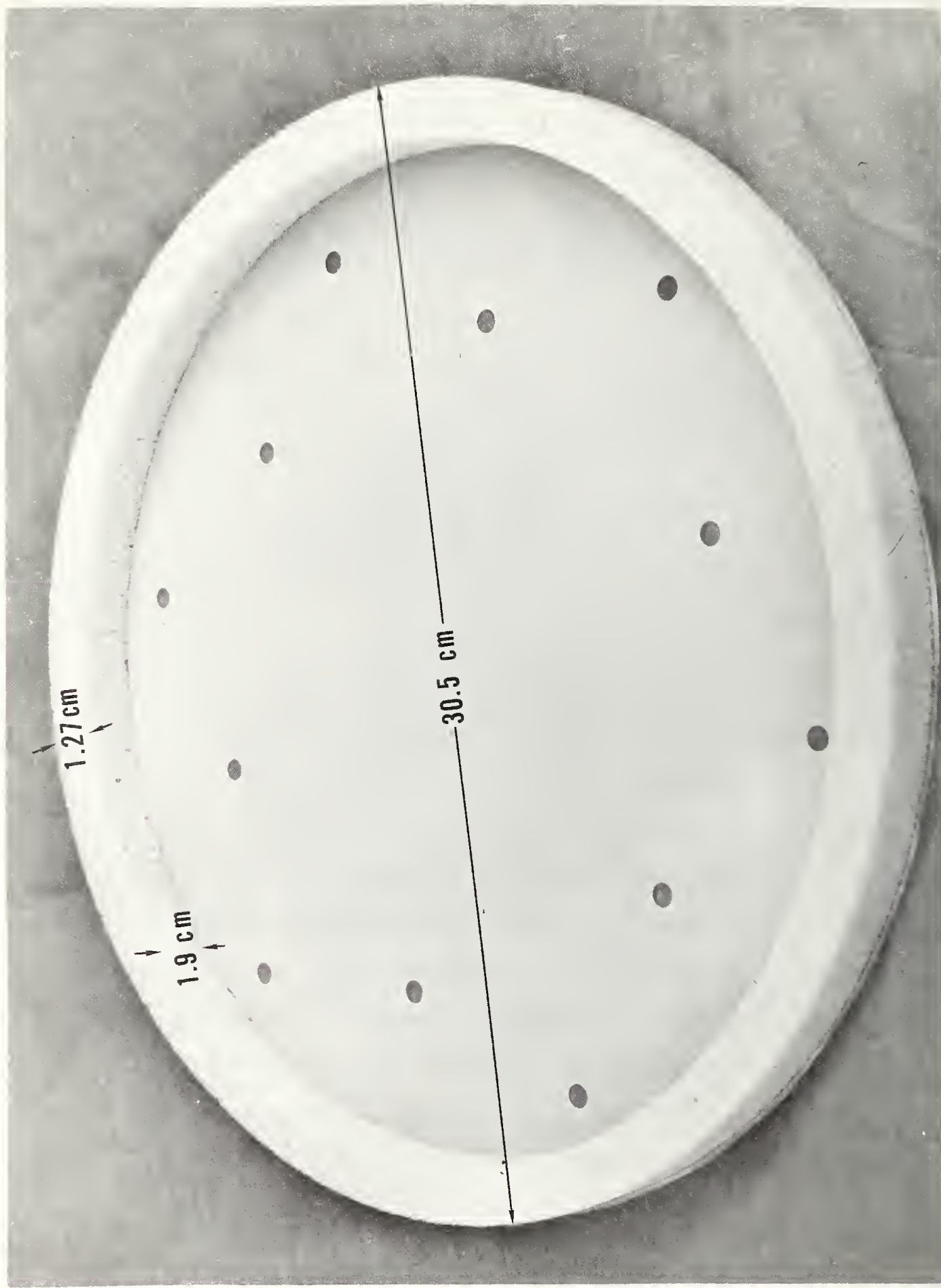

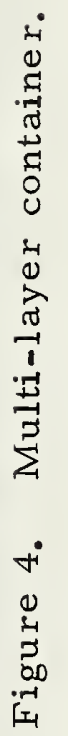




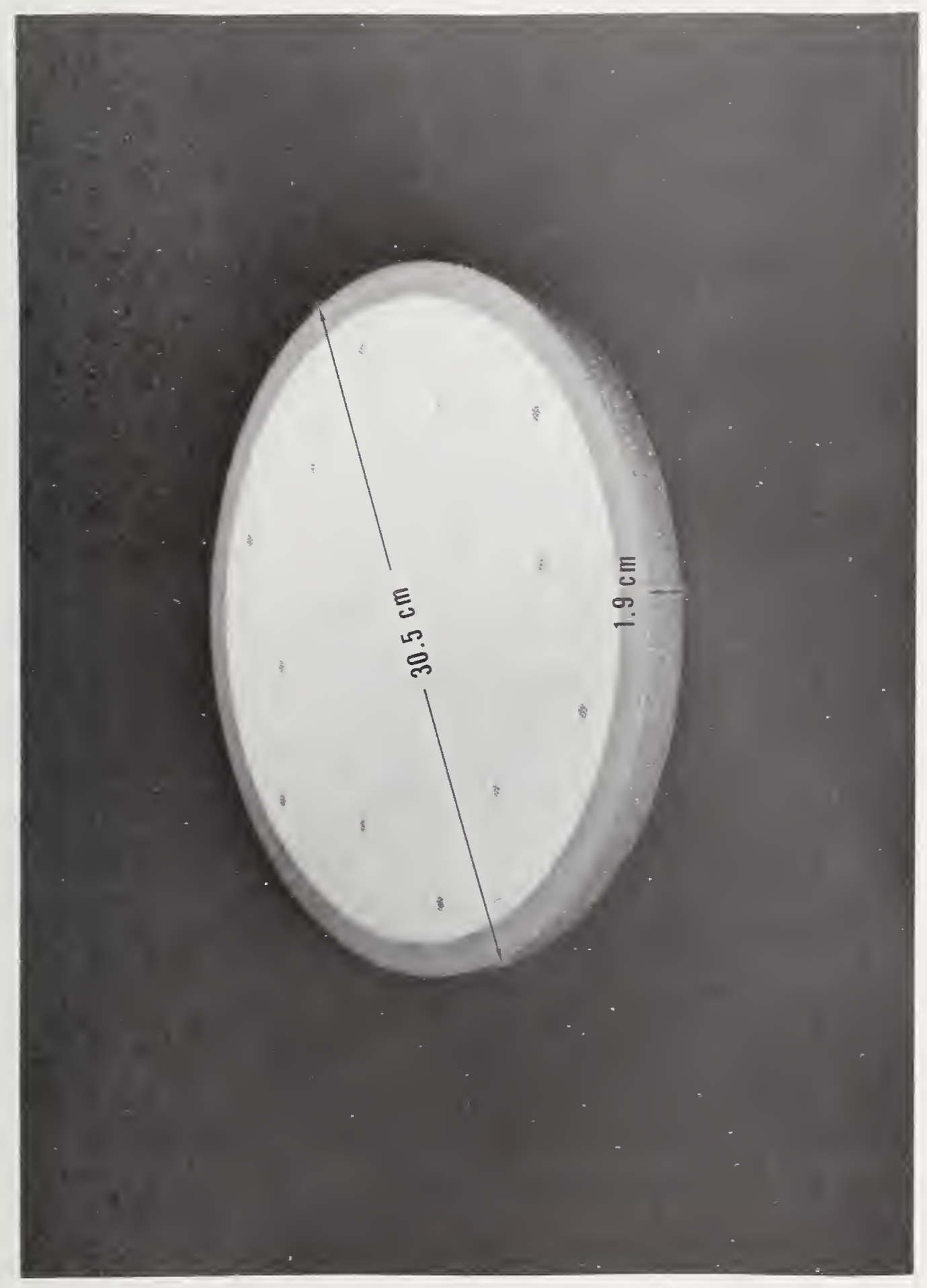

0
0
0
0
0
0
0
0
0
0
0
0
0
0
0
0
0
0
0
0
0
0
0
0
0
0
0
0
0
0
0
0
0
0
0 


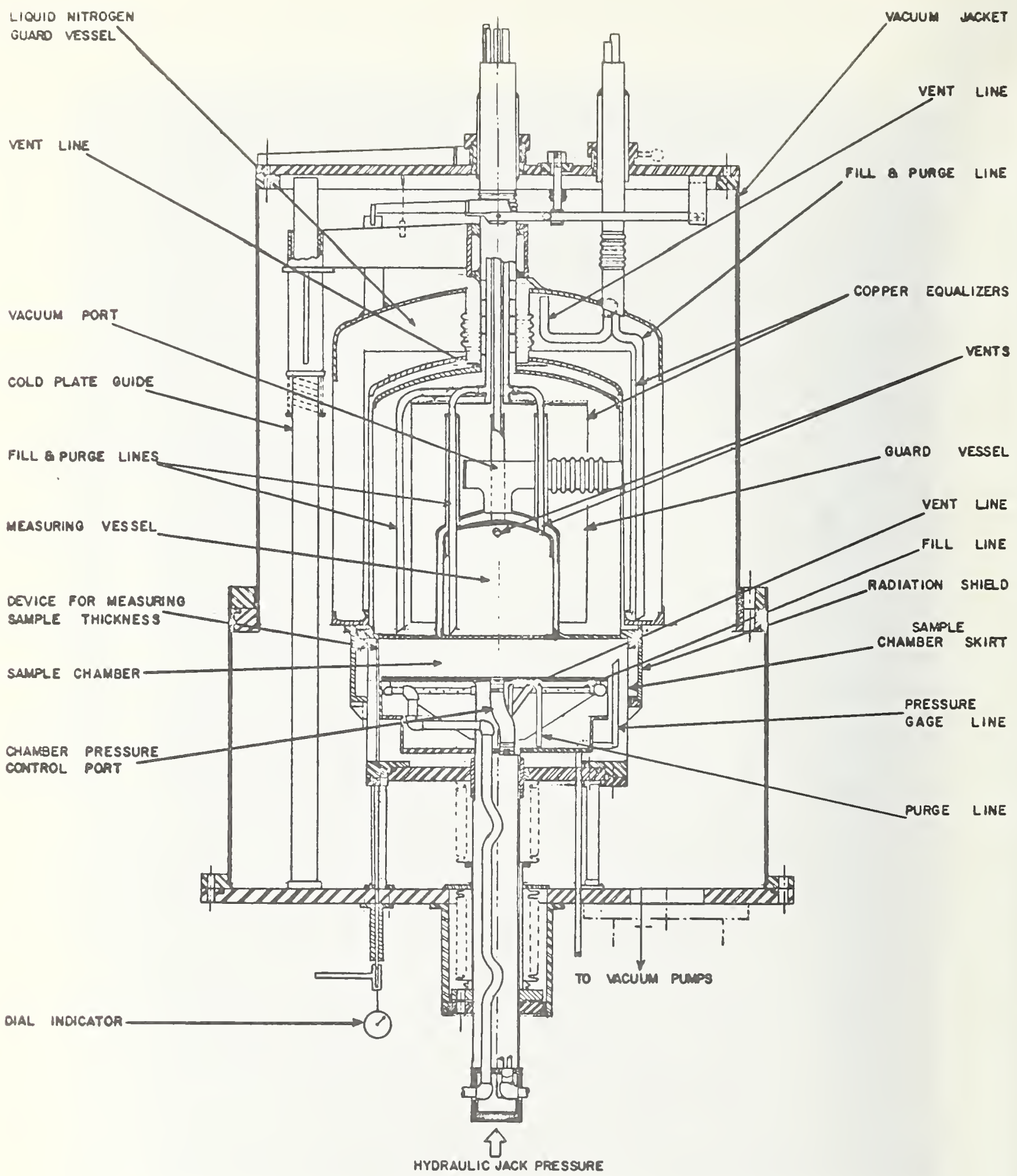

Figure 6. Double Guarded Flat Plate Calorimeter 
3) That the boiloff gas be bubbled through a larger water bath containing ceramic balls or marbles in order to achieve better saturation of the boiloff gas.

4) That an accurate means of determining the warm plate temperature of the calorimeter be implemented - new thermocouples should be installed in the warm plate to provide accurate temperature sensors at various locations on the surface of the warm plate.

5) That temperature sensors be installed on the sample skirt so that the skirt temperature can be monitored and recorded. The skirt is the cylindrical enclosure around the periphery of the sample.

6) That a pressure controller be used on the guard vessel to maintain a pressure difference of 133 to $266 \mathrm{n} / \mathrm{m}^{2}$ (1 to 2 $\mathrm{mm} \mathrm{Hg}$ ) between the guard and measuring vessels.

7) That the measuring vessel and all boiloff gas piping be checked for leakage with a mass spectrometer leak detector.

After reviewing the above recommendations, MSFC personnel agreed that every effort should be made to implement them. NBS personnel worked with technicians at the MSFC calorimeter site to make the following modifications to the calorimeter:

a) New copper-constantan thermocouples were installed at four locations in the warm plate of the calorimeter. At the same time a gold ( 0.07 atomic percent iron) vs Type KP thermocouple was provided to that a thermocouple circuit could be installed on the sample skirt at a future date.

b) Two cartesian-diver type manostats were installed; one on the measuring vessel and another on the guard vessel. Both 
of these pressure controllers were placed in a temperature controlled oil bath in order to obtain maximum pressure control on each of these vessels.

c) A new wet test meter was purchased and installed to measure boiloff gas.

d) Glass marbles were installed in the water saturator container and the water level was increased to $13 \mathrm{~cm}$ depth.

e) A pressure check of the measuring vessel and all piping for boiloff gas was conducted to check for leaks.

The following recommendations were made in order to improve the accuracy of the boiloff gas data reduction procedures.

1) That a correction term be added to the data reduction program for boiloff gas measurements to compensate for the gas that is vaporized without leaving the measuring vessel. This gas occupies the space left by the vaporized liquid.

2) That a more accurate temperature of the warm plate be used. This is obtained by using an arithmetic average of the temperature measured by the four warm plate thermocouples.

3) That the exact temperature (to $0.1 \mathrm{~K}$ ) of the calorimeter cold plate be used. This is determined from the vapor pressure of the fluid in the measuring vessel.

4) That a mercury manometer correction term of $453 \mathrm{n} / \mathrm{m}^{2}$ ( $3.4 \mathrm{~mm} \mathrm{Hg}$ ) be subtracted from the actual pressure readings. This correction term would compensate for the temperature and gravity corrections to the manometer readings at $\mathrm{MSFC}$. 
5) That the precise values for density and latent heat of vaporization be used for the fluid in the measuring vessel, instead of arbitrarily using values for liquid at one atmosphere.

6) That a more precise value of 459.7 be used instead of 460 when correcting Fahrenheit temperature readings to the Rankine scale.

It was agreed that each of the above recommendations would increase the accuracy of the thermal conductivity measurements. All of the above recommendations were incorporated in the data reduction program.

\section{0 Draft of an Interim Operating Procedure}

An interim test procedure was drawn up to be used when testing the various candidate materials in the calorimeter using liquid nitrogen. The purpose of this procedure was to insure that each of the same type of samples would be tested uniformly. It was decided that the closed cell foams should be tested in a nitrogen environment at a constant pressure of one standard atmosphere $(760 \mathrm{~mm} \mathrm{Hg})$ and fiber glass samples will be tested under evacuated conditions with a pressure $\leq 0.00133 \mathrm{n} / \mathrm{m}^{2}\left(10^{-5} \mathrm{~mm} \mathrm{Hg}\right)$. A method of preconditioning the samples was specified in order to remove the moisture from the samples and to define the gas remaining within the interstitial spaces or layers of the samples.

The multi-layer samples will not be tested using liquid nitrogen because the resultant boiloff rate would be too low to establish confidence in the test results. All of the multi-layer samples will be tested using liquid hydrogen. A different interim test procedure will be drafted for testing the multi-layer samples. 


\section{1 Typical Test Procedure}

A typical thermal conductivity test schedule and procedure used during the screening tests is described below. Each thermal conductivity test requires a 1 -week period. The closed cell foam samples were tested in a one standard atmosphere nitrogen environment with approximately $6895 \mathrm{n} / \mathrm{m}^{2}$ (one $\mathrm{lb} / \mathrm{in}^{2}$ ) compressive force on the sample.

\section{1. 1 Closed Cell Foam Transfer-Standards}

Friday 1) Disassemble calorimeter and remove sample. Examine sample for cracks or physical defects.

F 2) Place a $0.005 \mathrm{~mm}(0.002$ in) thick stainless steel diaphragm and an O-ring in position in order to seal the sample chamber from the insulating vacuum space.

F 3) Place a new sample in the calorimeter and apply a compressive force of approximately $6895 \mathrm{n} / \mathrm{m}^{2}$ (one $1 \mathrm{~b} / \mathrm{in}^{2}$ ) to the foam sample using the hydraulic jack.

F 4) Record initial thickness of the sample.

F 5) Assemble the calorimeter.

F 6) Evacuate the insulating vacuum space and check for leakage past the O-ring seal into the sample chamber. Continue pumping the insulating vacuum with the fore pump.

F 7) Through-purge the sample chamber with nitrogen gas for 30 minutes to remove most of the air from the sample chamber. Seal the sample chamber at one standard atmosphere pressure.

F 8) Conduct a pressure decrease vs time leak check on the measuring vessel and all connecting piping at $68948 \mathrm{n} / \mathrm{m}^{2}$ $\left(10 \mathrm{lb} /\right.$ in $\left.^{2}\right)$ for 15 minutes. Any pressure decrease will 
indicate leakage in the measuring vessel system; the leak must be sealed before continuing with the test.

F 9) Check each of the absolute manometers on the measuring and guard vessels for leakage and consistency with the barometer.

Saturday \&

Sunday) Continue pumping the insulating vacuums during the weekend with the fore pump.

Monday 1) Check the pressure in the sample chamber for an indication of leakage past the O-ring.

M 2) Fill the calorimeter shield with liquid nitrogen. Monitor the pressure levels while filling the shield for any indication of leakage past the O-ring.

M 3) Start the diffusion pump for the insulating vacuum space.

M 4) Maintain the pressure in the sample chamber at one standard atmosphere with nitrogen gas.

Tuesday 1) Check the pressure and vacuum in the various chambers.

$\mathrm{Tu}$ 2) Refill the shield with liquid nitrogen.

Tu 3) Fill the guard and measuring vessels with liquid nitrogen.

Wednesday 1) Check the pressure and vacuum in the various chambers. The insulating vacuum should be at least $0.0013 \mathrm{n} / \mathrm{m}^{2}$ $\left(10^{-5} \mathrm{~mm} \mathrm{Hg}\right)$.

W 2) Refill the shield, the guard, and the measuring vessel with liquid nitrogen.

W 3) Check the hydraulic system to maintain $6895 \mathrm{n} / \mathrm{m}^{2}$ (one lb/in ${ }^{2}$ ) pressure on the sample. 
W 4) Set the cartesian diver manostats to control the measuring vessel pressure at $109,573 \mathrm{n} / \mathrm{m}^{2}(822 \mathrm{~mm} \mathrm{Hg})$, and to control the guard vessel pressure at $109,839 \mathrm{n} / \mathrm{m}^{2}(824 \mathrm{~mm}$ $\mathrm{Hg})$ pressure. $\left(109,573 \mathrm{n} / \mathrm{m}^{2}(822 \mathrm{~mm} \mathrm{Hg})\right.$ will maintain the measuring vessel temperature at exactly $78 \mathrm{~K}$, considering the temperature and gravity corrections to the manometer readings. )

W 5) Maintain the specified pressure control on the measuring and guard vessels for an additional 8 hours of controlledpressure test time.

W 6) During the 8-hour period, record the following data every 30 minutes: insulating vacuum pressure, sample chamber pressure, warm plate temperature (4 thermocouples), measuring vessel pressure, guard vessel pressure, barometric pressure, wet test meter reading, wet test meter temperature, manostat oil bath temperature, hydraulic pressure, sample thickness, and the pressure difference between the measuring and guard vessels $\left(\mathrm{mm} \mathrm{H}_{2} \mathrm{O}\right)$.

W 7) After the 8-hour period, blow the liquid nitrogen out of the measuring vessel, guard vessel, and shield.

W 8) Valve off and turn off the diffusion pump.

Thursday 1) Valve off the fore pump and pressurize the insulating vacuum space to approximately one standard atmosphere with nitrogen gas.

Th 2) Allow the calorimeter to warm to ambient temperature. This completes the test cycle. 


\section{1.2 Open Cell Foam Samples}

The test procedure for the open cell foam samples is the same as for the closed foam samples, except:

1) There is no stainless steel diaphragm and accompanying O-ring to contend with; the sample chamber and insulating vacuum are common, and both are evacuated to $\leq 0.00133$ $\mathrm{n} / \mathrm{m}^{2}\left(10^{-5} \mathrm{~mm} \mathrm{Hg}\right)$ pressure.

2) The foam sample is initially preconditioned by evacuating to approximately $1.33 \mathrm{n} / \mathrm{m}^{2}(0.01 \mathrm{~mm} \mathrm{Hg})$ pressure and subsequently pressurizing to one standard atmosphere with nitrogen gas. This cycle is repeated three times to help remove moisture from the sample and remove all air from the sample chamber, (i. e., to insure that the residual gas is mostly nitrogen).

\section{1. 3 Fiber Glass and Multi-Layer Sandwiches}

The test procedure for the fiber glass and multi-layer sandwiches is the same as for the open cell foam samples except the 6895 $\mathrm{n} / \mathrm{m}^{2}$ (one $\mathrm{lb} / \mathrm{in}^{2}$ ) compressive force is not placed on these samples. After installing the sandwich sample, the calorimeter sample spacing is set and locked at either 1.9 or $3.81 \mathrm{~cm}$, whichever is the thickness of the sandwich sample. The fiber glass and multi-layer samples are preconditioned using nitrogen gas in the same manner as the open cell foam samples.

After gaining experience with the calorimeter during the screening tests using both liquid nitrogen and hydrogen, a final standard operating procedure will be drafted for the repeatability tests. The procedure for testing the multi-layer samples will be as consistent as 
possible with the ASTM Standard Method of Test for Heat Flux Through Evacuated Insulations, presently in its fifth draft.

\section{0 Preliminary Screening Tests with the MSFC Calorimeter on Selected Candidate Transfer-Standards}

During the period from February through August 1972, twentytwo thermal conductivity tests were conducted using liquid nitrogen in the calorimeter at NASA-Marshall Space Flight Center. The results of these tests along with all pertinent data are given in table 2. Some of the tests were scrapped because of difficulties in controlling the measuring vessel pressure or guard vessel pressure, or other technical difficulties. The test data presented is for tests with good pressure control and consistent boiloff during the test period.

\section{1 Discussion of Test Results}

\section{1. 1 Closed Cell Foams}

Two different types of closed cell foams are being tested: one type is a polystyrene or polyurethane foam containing chlorofluorocarbon gas within the cells, and the other is a polyurethane foam containing carbon dioxide gas within the cells. A total of eight calorimeter tests have been conducted on the closed cell foam samples.

The very first test with the NBS-MSFC-3 sample produced a thermal conductivity value slightly less than the values obtained in subsequent tests. The low thermal conductivity value was undoubtedly due to the fact that the sample was freshly cut and the cells near the exterior of the sample still contained a high concentration of chlorofluorocarbon gas, and very little air or nitrogen had diffused into the foam. After conducting several additional tests on this same sample, we verified that the changing composition of the gas within the foam 
cells has a significant effect on the thermal conductivity of the samples. Thus, in order to provide a closed cell foam sample of constant thermal conductivity, the gas composition within the sample must remain reasonably constant over an extended period of time.

One method of obtaining a nearly constant gas composition is to shorten the time required to achieve gas equilibration between the foam sample and the nitrogen environment that the sample experiences during the 6-day testing period. This technique was tried; two closed cell samples were placed in a bell jar and evacuated to a pressure of approximately $1.33 \mathrm{n} / \mathrm{m}^{2}(0.01 \mathrm{~mm} \mathrm{Hg})$. The samples were maintained at this pressure for a period of 11 days. After the 11 -day period the samples were pressurized to $83,979 \mathrm{n} / \mathrm{m}^{2}(630 \mathrm{~mm} \mathrm{Hg})$ with nitrogen gas and they were kept in this environment for 40 hours before they were sealed in metal containers. One of the samples initially had chlorofluorocarbon gas within the cells and the other had carbon dioxide within the cells. These are samples numbered NBS-MSFC-3E and NBS MSFC-4E, respectively.

The amount of parent gas pumped from the samples and subsequently replaced with nitrogen gas is indeterminate. However, the thermal conductivity values obtained from the four tests with these preconditioned samples are very consistent.

Three different tests were conducted with foam containing carbon dioxide gas within the cells.

The first test on 3-29 gave a thermal conductivity value of $260 \mu \mathrm{W} / \mathrm{cm}-\mathrm{K}$. The following two tests with the pre-evacuated sample NBS-MSFC-3E produced thermal conductivity values very close to the value obtained with the regular sample NBS-MSFC-4. The slight increase 


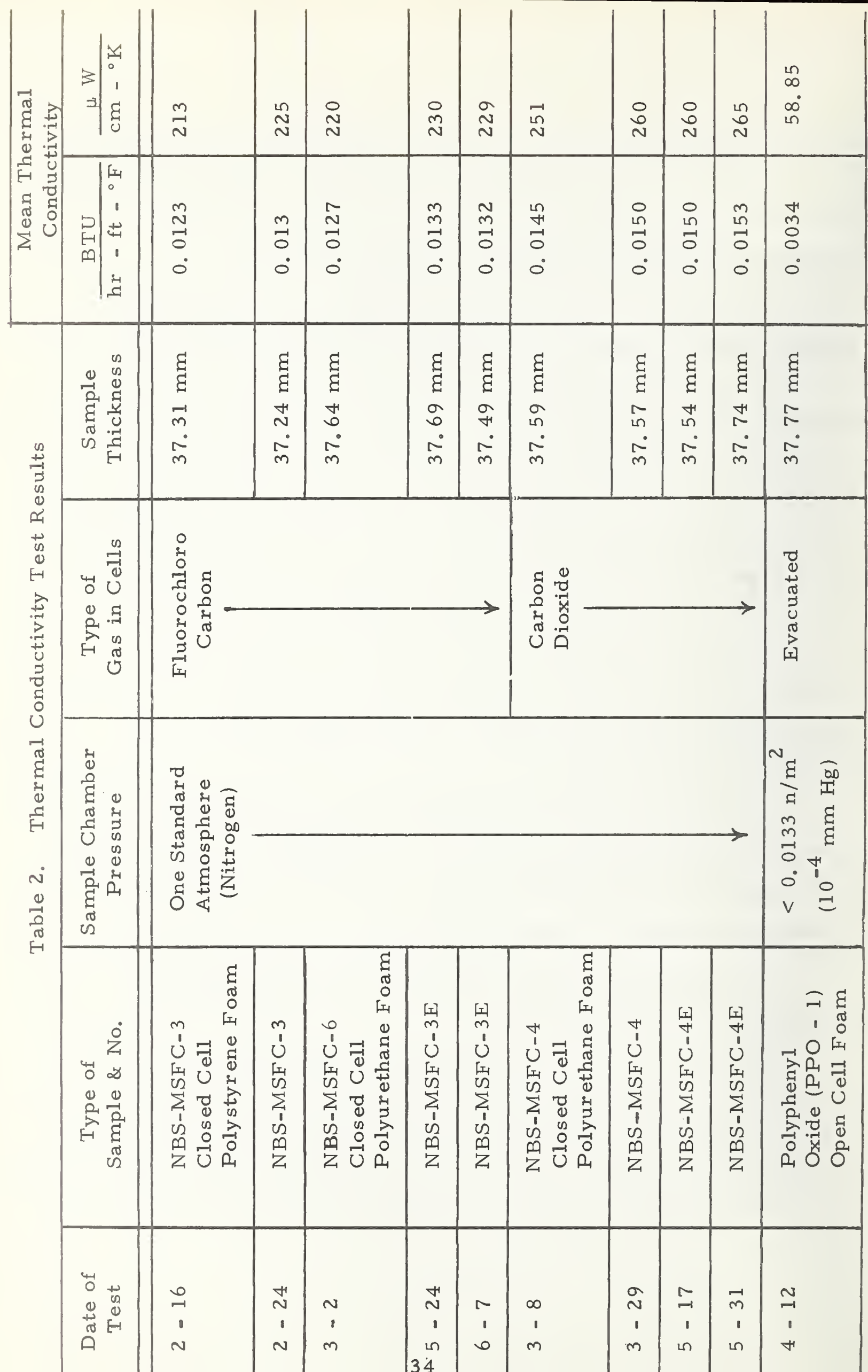




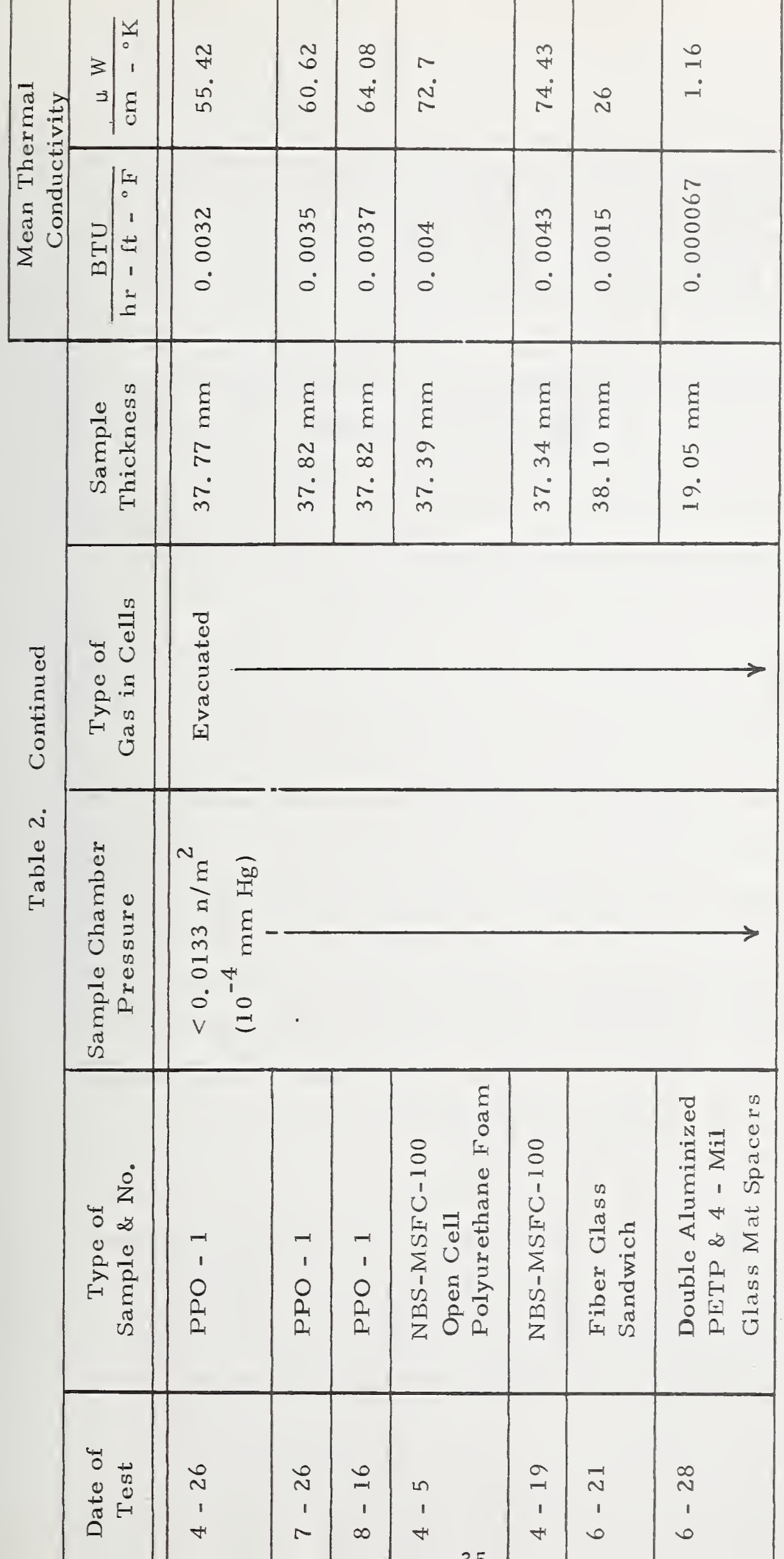


in thermal conductivity obtained with the test on 5-31 is insignificant. Carbon dioxide gas diffuses from foam faster than chlorofluorocarbon gas and consequently the foam has a faster equilibration rate. This may be why there is no significant difference between the regular and the pre-evacuated samples.

From the screening tests that have been conducted on the closed cell foams, several decisions have been made. 1) No further testing will be done on the NBS-MSFC-6 foam. This foam has a distinct tendency to dust at the surface and offers no significant advantages over the NBS-MSFC-3 foam which has approximately the same thermal conductivity and a much harder, non-dusting surface.

The predominate variable in trying to obtain a closed cell foam with constant thermal conductivity is the composition of the gas within the cells of the foam (see figure 1). It should be noted that there is considerable difference between the thermal conductivity of nitrogen and the chlorofluorocarbon gases usually present in the closed cell foams.

At this point in the program the pre-evacuated samples and the NBS-MSFC-4 foam blown with carbon dioxide appear to be most promising as candidates for standard reference materials chosen from the closed cell foams. Forthcoming repeatability tests with these materials will reveal the magnitude of the variations in thermal conductivity due to changing gas composition over an extended period of time.

\subsubsection{Open Cell Foams}

A total of six thermal conductivity tests have been conducted using open cell foam samples. Four tests have been conducted on polyphenyloxide (PPO) and another two tests have been conducted on an experimental open cell foam NBS-MSFC-100. The thermal conductivity 
values obtained with the NBS-MSFC-100 open cell foam are very consistent but of significantly higher value. At the present time, the PPO appears to be the better contender for use as a standard reference material because of its more uniform density, non-dusting characteristics, and its more open structure which allows a more thorough evacuation of the sample. Additional tests will be conducted on both of the se materials during the repeatability phase of testing.

\section{1. 3 Fiber Glass Transfer-Standard}

Only one test was conducted on the fiber glass sandwich sample, and during this test the guard pressure was not controlled properly。 Additional testing will have to be conducted with this sample in order to check the consistency of the thermal conductivity values.

\section{1.4 Multi-Layer Transfer-Standard}

One test was conducted on a $1.9 \mathrm{~cm}$ thick multi-layer sandwich sample composed of double aluminized PETP film and glass mat spacer material. The test was conducted using liquid nitrogen. The gas boiloff rate during the test was only $0.114 \mathrm{~cm}^{3} / \mathrm{sec}\left(0.014 \mathrm{ft}^{3} / \mathrm{hr}\right)$, an extremely low gas boiloff rate. Because of this, the multi-layer samples will all be tested using liquid hydrogen, which will give a boiloff rate approximately 5 times the above rate.

The screening tests conducted to date have provided information about the candidate samples (exclusive of the multi-layer region). None of the foam samples have experienced any type of cracks or other physical defects due to the cryogenic temperatures, and the epoxy bond between the PETP film and open cell annular ring of foam shows no sign of failure or other adverse affects. Initially, there was concern about the integrity of this epoxy joint at cryogenic temperatures. 
The estimated measurement uncertainty of the mean thermal conductivity values presented in table 2 is $\pm 10 \%$. This is the measurement uncertainty specified by the manufacturer of the calorimeter.

\section{0 Future Work}

Additional repeatability tests using liquid nitrog en will be conducted on the closed and open cell foam samples and the fiber glass samples. These tests will be conducted in order to determine which sample materials give the most consistent thermal conductivity values.

Screening tests will be conducted on the candidate multi-layer transfer-standards using liquid hydrogen. However, before the screen-ing tests are started on the multi-layer samples, additional upgrading of the MSFC calorimeter will be performed, Every effort will be made to upgrade the calorimeter and operating procedure to be consistent with the ASTM Standard Method of Test for Measuring Heat Flux Through Evacuated Insulations. 
FORM NBS-114A (1.71)

\begin{tabular}{|c|c|c|c|}
\hline $\begin{array}{l}\text { U.S. DEPT. OF COMM. } \\
\text { BIBLIOGRAPHIC DATA } \\
\text { SHEET }\end{array}$ & $\begin{array}{l}\text { 1. PUBLICATION OR REPORT NO. } \\
\text { NBSIR 73-301 }\end{array}$ & $\begin{array}{l}\text { 2. Gov't Accession } \\
\text { No. }\end{array}$ & 3. Recipient's Accession No. \\
\hline \multirow{2}{*}{\multicolumn{3}{|c|}{$\begin{array}{l}\text { 4. TITLE AND SUBTITLE } \\
\text { Development of Insulation Transfer-Standards } \\
\text { Using a Flat Plate Calorimeter }\end{array}$}} & $\begin{array}{l}\text { 5. Publication Date } \\
\text { March } 1973\end{array}$ \\
\hline & & & 6. Performing Organization Code \\
\hline \multicolumn{3}{|l|}{$\begin{array}{l}\text { 7. AUTHOR(S) } \\
\text { Paul R. Ludtke }\end{array}$} & $\begin{array}{l}\text { 8. Performing Organization } \\
\text { NBSIR 73-301 }\end{array}$ \\
\hline \multicolumn{3}{|c|}{$\begin{array}{l}\text { NATIONAL BUREAU OF STANDARDS, Boulder Labs. } \\
\text { DEPARTMENT OF COMMERCE } \\
\text { Boulder, Colorado } 80302\end{array}$} & $\begin{array}{l}\text { 10. Project/Task/Work Unit No. } \\
275.05-2750457 \\
\text { 11. Cuntract/Grant No. } \\
\text { H-79204A }\end{array}$ \\
\hline \multirow{2}{*}{\multicolumn{3}{|c|}{$\begin{array}{l}\text { 12. Sponsoring Organization Name and Address } \\
\text { NASA-Marshall Space Flight Center } \\
\text { Astronautics Laboratory } \\
\text { Materials Division } \\
\text { Huntsville, Alabama }\end{array}$}} & $\begin{array}{l}\text { 13. Type of Report \& Period } \\
\text { Covered }\end{array}$ \\
\hline & & & 14. Sponsoring A gency Code \\
\hline
\end{tabular}

15. SUPLEMENTARY NOTES

16. ABSTRACT (A 200-word or less factual summaty of most significant information. If document includes a significant bibliography or literature survey, mention it here.)

This program was initiated to develop insulation transfer-standards to be used for evaluating calorimeters at different locations throughout the country. Various types of insulation materials were evaluated for use as transfer-standards. Samples were prepared for preliminary evaluation from selected candidate insulation materials A $30.5 \mathrm{~cm}$ diameter double guarded flat plate calorimeter at MSFC was provided for testing. The calorimeter was checked and the boiloff-gas instrumentation updated. Thermal conductivity screening tests were conducted using liquid nitrogen on open and closed cell foam and fiber glass samples. The mean thermal conductivity values of the samples tested during the screening tests are presented. Compliance with the proposed ASTM Standard Method of Test for Heat Flux Through Evacuated Insulations was stressed.

17. KEY WORDS (Alphabetical order, separated by semicolons)

Calorimeters; fiber glass; foam insulation; insulation transfer-standard; multi-layer insulation; thermal insulation; transfer standards

18. AVAILABILITY STATEMENT

UNL IMIT ED.

$\mathrm{X}$ FOR OFFICIAL DISTRIBUTION. DO NOT RELEASE TO NTIS.

\begin{tabular}{|l|l|}
\hline $\begin{array}{l}\text { 19. SECURITY CLASS } \\
\text { (THIS REPORT) }\end{array}$ & 21. NO. OF PAGES \\
UNCL ASSIF IED & \\
\hline $\begin{array}{l}\text { 20. SECURITY CLASS } \\
\text { (THIS PAGE) }\end{array}$ & 22. Price \\
UNCL ASSIFIED &
\end{tabular}


